\title{
A CASE STUDY ABOUT DEGRADATION OF THE BUILDINGS AND THEIR BUILDINGELEMENTS AS A RESULT OF CLIMATE CHANGE
}

\author{
Gheorghe Croitoru*, ORCID ID: 0000-0001-6289-8897 \\ Technical University of Moldova, 168 Stefan cel Mare blvd., Chisinau, Republic of Moldova \\ *Corresponding author: Gheorghe Croitoru, gheorghe.croitoru@dmmc.utm.md
}

Received: 10. 22. 2021

Accepted: 11. 26. 2021

\begin{abstract}
The article deals with the problems of climate change and global warming, extreme climate phenomena, which present risk factors for the national economy, including construction. The causes that lead to the occurrence of the construction degradation phenomena are diverse and may be specific to improper exploitation, but also as a consequence of extraordinary natural phenomena or results from the humanity's interrelationship with the environment. The degradation of the constructions is manifested by the gradual loss of the physical and functional qualities that characterize the aptitude for their exploitation, the degradation process manifesting itself starting from the contact surfaces of the constructions with the environment. Urban planning and the design of adequate infrastructure play an important role in minimizing the impact of climate change and reducing the risk to the human environment. The undertaking's measures, which will consider the potential impact of climate change on buildings, will provide opportunities for new markets for climate change-resistant technologies, machinery, materials, and products.
\end{abstract}

Keywords: climate variability, construction degradation, extreme climate phenomena, global warming, maintenance of buildings, project planning, risk management.

Rezumat. În articol sunt tratare probleme legate de efectele schimbărilor climatice şi a încălzirii globale, a fenomenelor climatice extreme care prezintă factori de risc pentru economia națională, inclusiv pentru domeniul construcțiilor. Cauzele care conduc la apariția fenomenelor de degradare a construcțiilor sunt diverse și pot fi specifice unei exploatări necorespunzătoare, dar și ca urmare a unor fenomene extraordinare naturale sau rezultate în urma interacțiunii dintre om și mediu. Degradarea construcțiilor se manifestă prin pierderea treptată a calităților fizice și funcționale ce caracterizează aptitudinea pentru exploatarea acestora, procesul de degradare manifestându-se începând de la suprafețele de contact ale construcțiilor cu mediul înconjurător. Planificarea urbană şi proiectarea unei infrastructuri adecvate joacă un rol important în minimizarea impactului schimbărilor climatice și reducerea riscului asupra mediului antropic. Întreprinderea măsurilor, care vor ține seama de impactul potențial al schimbărilor climatice asupra construcțiilor, vor oferi oportunități pentru piețe noi de tehnologii, utilaje, materiale și produse de construcții rezistente la efectele schimbărilor climatice. Cuvinte cheie: abordarea planificării, degradarea 
construcțiilor, fenomene climatice extreme, încălzire globală, management al spațiului, minimizarea riscului, schimbări climatice.

Cuvinte cheie: abordarea planificării, degradarea construcțiilor, fenomene climatice extreme, încălzire globală, management al spațiului, minimizarea riscului, schimbări climatice.

\section{Introduction}

The effects of climate change cause global warming, generating huge losses for the economy of the Republic of Moldova. These phenomena, in the form of strong wind gusts, floods, torrential rainfall, large hail, frost, excessive solar radiation that causes heat waves, low temperatures that in winter cause major damage to buildings, such as buildings, bridges, towers, power line poles, roads, dams, metal constructions, technological installations and equipment, historical and art monuments, etc., which induce serious risks to the health and safety of the population.

The complex action of these natural and technological environmental agents (chemical, physico-chemical, biological), as well as created errors by the existence of defects produced in the design and execution of construction works, considerably diminishing their exploitation and existence.

The causes that lead to the occurrence of construction degradation phenomena (see "Table 1") are diverse and may be specific to improper exploitation, as also according to extraordinary natural phenomena or resulting from the humanity's interrelationship with the environment [1].

The great climate variability of the last decades requires detailed and permanent research to consider the attested climate changes, both in making various applicable decisions and in the correct adaptation to these changes.

Knowledge to action of these climate phenomena is extremely important, to foresee in the future measures to minimize the consequences in different areas of the national economy.

Table 1

Table 1 Physico-chemical degradation factors in constructions

\begin{tabular}{cccc}
\hline The risk factors & $\begin{array}{c}\text { Nature } \\
\text { factor }\end{array}$ & $\begin{array}{c}\text { Time period } \\
\text { occurrence }\end{array}$ & $\begin{array}{c}\text { Probability of } \\
\text { occurrence }\end{array}$ \\
\hline $\begin{array}{c}\text { Natural factors } \\
\text { hail, solar radiation }\end{array}$ & physics & $\begin{array}{c}\text { of long } \\
\text { continuance }\end{array}$ & continuous cycles \\
\hline Humidity, temperature (variations) & physics & $\begin{array}{c}\text { of long } \\
\text { continuance }\end{array}$ & continuous cycles \\
\hline Strong winds & physics & $\begin{array}{c}\text { of long } \\
\text { continuance }\end{array}$ & continuous cycles \\
\hline Polluted air & physics & $\begin{array}{c}\text { of long } \\
\text { continuance } \\
\text { of long } \\
\text { continuance }\end{array}$ & continuous cycles \\
\hline & physics & continuously \\
\hline
\end{tabular}


Continuation Table 1

\begin{tabular}{cccc}
\hline $\begin{array}{c}\text { Land movements (deformations, } \\
\text { displacements) because of soil } \\
\text { wetting }\end{array}$ & physics & $\begin{array}{c}\text { of long } \\
\text { continuance }\end{array}$ & continuously \\
\hline Landslides & physics & $\begin{array}{c}\text { Quick } \\
\text { installation }\end{array}$ & rare \\
\hline Factors resulting from the relationship man - construction - environment \\
\hline $\begin{array}{c}\text { Pollution } \\
\text { Corrosive actions (aggregate alkali } \\
\text { reaction, expansive cements) }\end{array}$ & corrosive & Medium & continuously \\
\hline
\end{tabular}

Studies [2] demonstrate the extremely variable time and space of basic climate parameters, which may contribute to the careful selection of measures to mitigate the consequences of climate change on various activities, including the construction sector in Moldova. Therefore, it is important to consider the climate parameters of recent years because they leave their mark on the manifestation of significant thermal and rainfall extremes.

\section{Degradation of buildings on environmental actions}

The constructions are executed to protect the users and their goods, to carry out specific activities. The term degradation, in the field of civil engineering, refers to any negative change in specific characteristics (physical, chemical, or mechanical) that may affect the strength, stability or durability of a constructed material, element or assembly [3].

Corrosion is one of the most common causes of damage in the industrial area, as well as one of the costliest. Corrosion is a phenomenon of gradual deterioration of materials, under the interaction with aggressive factors present in the atmosphere.

An important source of building degradation is water infiltration, which favors the appearance of wetlands. Their occurrence may be due to natural causes, due to heavy rainfall or due to mistakes in the stages of execution of a construction project.

Degradation of buildings is manifested by the loss over time of physical and functional characteristics, which diminish their ability to operate. This process of degradation is manifested, mainly at the contact surface of the buildings with the environment. In buildings, such manifestations occur by uneven discoloration of facades, by disintegration of plasters, by wetting and staining the surfaces of building elements, by the appearance of efflorescence on masonry and rust stains due to excessive moisture, rot on wooden elements, attack of anaerobic bacteria etc.

The main components of the atmosphere, which act corrosively on metallic elements are excessive humidity in the atmosphere, oxygen $\left(\mathrm{O}_{2}\right)$ and carbon dioxide $\left(\mathrm{CO}_{2}\right)$. In addition, other components can be added, depending on the types of atmospheres, for example sulfur dioxide $\left(\mathrm{SO}_{2}\right)$ in the atmosphere of industrial and urban areas.

In addition to the above mentioned, another phenomenon of influence in the stage of exploitation of buildings is the natural degradation of materials, regardless of their type and characteristics or the performance of periodic maintenance and maintenance of buildings.

In the case of roads, with asphalt or cement concrete pavements, the defects are manifested by cracks, potholes, open joints, exfoliated surface etc., and on pavements made 
of concrete slabs, by surface pinches, cracks, chipped edges, etc. In the case of bridges, the degradations are manifested by the erosion of the concrete at the joints, the rusting of the steel parts and elements, the rot and degradation of the wooden structures etc.

In the case of masonry, damage is manifested by the disintegration of plasters and exposed masonry systems, the reduction of the mechanical strength of masonry blocks (especially limestone masonry) and connecting mortars, by the disintegration of porous surfaces because of freezing cycles. thawing, due to the phenomenon of dampness, due to the persistent moisture retained in the pores of the masonry, due to the surface efflorescence etc. As degradation progresses into the constructive components of the construction elements, over time the safety of the constructions may be affected by changing the relationships considered permissible between stresses and strengths.

The decrease in the characteristics of concrete and reinforced concrete elements and structures is due, first of all, to the destructive actions of environmental phenomena (major seismic actions to which the territory of the Republic of Moldova is exposed, corrosive atmospheric environment, rain and wind storms, strong gusts of wind, catastrophic floods, explosions accompanied by fires, lightning with electric discharges etc.), but also as a result of the inappropriate attitude of some specialists in the process of design and execution of construction works [4].

\section{Concrete Degradation through corrosion}

The factors that influence the corrosion process of cement stone in concrete and its aggregates are physical, chemical, and biochemical.

The temperature variation of the environment is one of the physical factors, which influences the corrosion of concrete constructions. The tensile loads, but also the destructive mechanical phenomena lead to the disintegration of the concrete, due to the temperature variations of the aggressive environment, generating contraction phenomena in the hydration process of the cement in the fresh concrete, to the variations of the level and movement of the aggressive liquid environment. which represent physical and chemical phenomena, which favor the corrosion process of constructions. The solubilization process, induced by aggressive agents of cement hydration products, especially $\mathrm{Ca}(\mathrm{OH})_{2}$, is the decisive physical phenomenon in concrete corrosion.

Chemical compounds in nature, in the form of salts and alkalis have a destructive action on concrete [5], destroying it to the point of losing the ability to exploit buildings.

The most important chemical compounds with destructive action are: magnesium hydroxide $\left(\mathrm{Mg}(\mathrm{OH})_{2}\right)$, which modifies the properties of cement; ammonium compounds, which decrease the mechanical strengths of limestone aggregates $\left(\mathrm{Ca}(\mathrm{OH})_{2}+2 \mathrm{NH}_{4}{ }^{+}=\mathrm{Ca}^{2+}+\right.$ $2 \mathrm{NH}_{4} \mathrm{OH}$ ) and which subsequently exfoliate the concrete; sulphates, in particular 0,05 $\mathrm{M}$ ammonium sulphate $\left.\left(\mathrm{NH}_{4}\right)_{2} \mathrm{SO}_{4}\right)$, generate volume increases, leading to cracks in the concrete mass and detachment of its pieces; chlorinated ions lower the $\mathrm{pH}$ of concrete below 9 , being a critical value that leads to corrosion of concrete reinforcement, with the effect of exfoliating it; the river water entails by washing the free lime from the cement generating a porous system in the concrete structures (at the bridge pillars); alkaline salts $\left(5 \% \mathrm{NaOH}, 5 \% \mathrm{NH}_{4} \mathrm{OH}\right)$ crystallize into compounds, which disintegrate the concrete by expansion, leaving traces of efflorescence.

For example, carbon dioxide $\left(\mathrm{CO}_{2}\right)$, present in the air of large cities (Chisinau, Balti, Cahul, Ungheni, Soroca etc.) in concentrations above the permissible limit, under the effect 
of moisture (from $50 \%$ to $80 \%$ ), by dissolution leads to the carbonation of concrete in cracks [6], forming insoluble calcium carbonate:

$$
\mathrm{Ca}(\mathrm{OH})_{2}+\mathrm{CO}_{2} \rightarrow \mathrm{CaCO}_{3}+\mathrm{H}_{2} \mathrm{O}
$$

Thus, the problem of conducting experimental research on reinforced concrete elements was raised, regarding the variation of air temperature and humidity when calculating the carbonation depth of the concrete protection layer of the reinforcement, given the action of the corrosive atmospheric environment of Chisinau, where - considered the high temperatures of March-November of 2020 (Figure 1 a). During this time of year, the relative humidity of the air varied in the range from $60 \%$ to $87 \%$, due to the annual amount of rainfall of $355-615 \mathrm{~mm}$ or $70 \%-105 \%$ of the norm (Figure $1 \mathrm{~b}$ ).

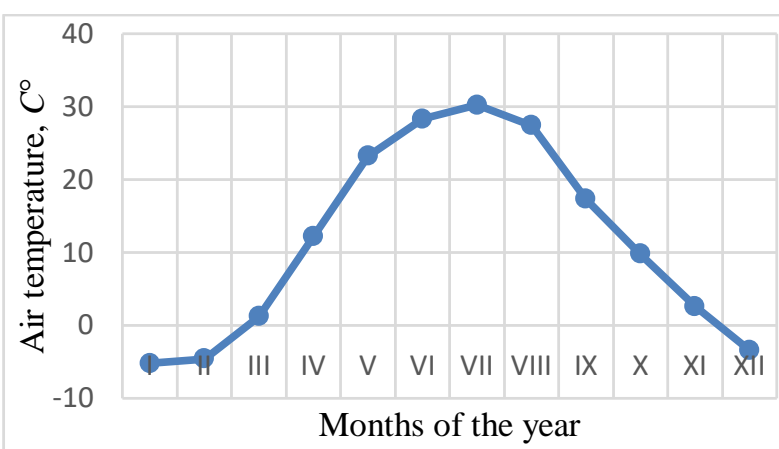

a)

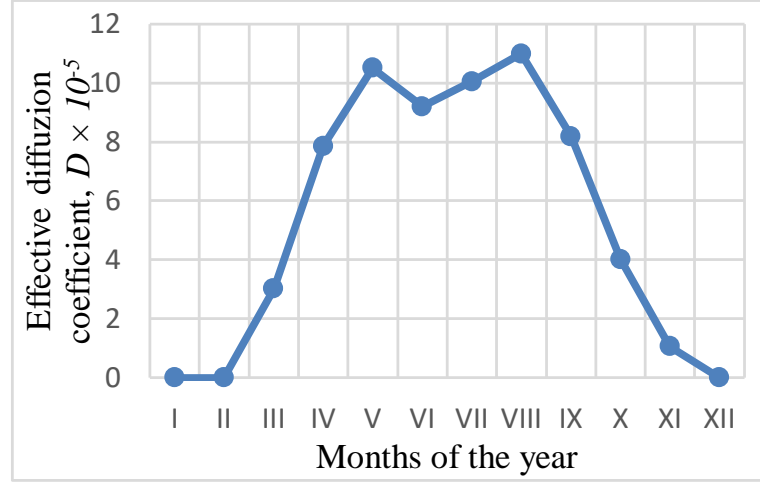

c)

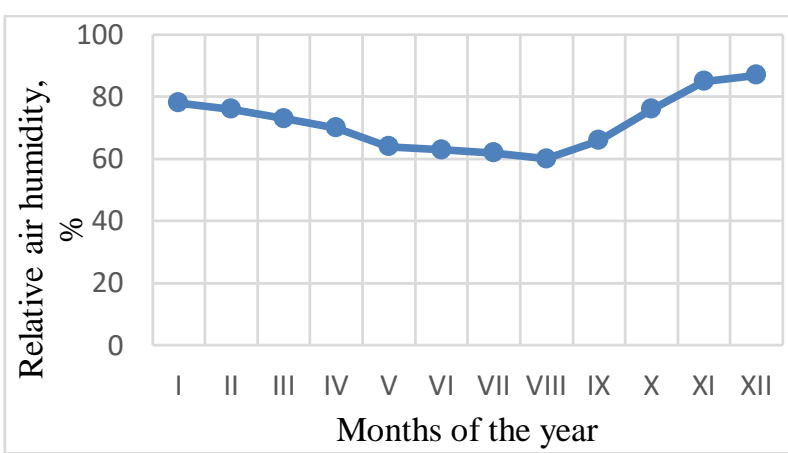

b)

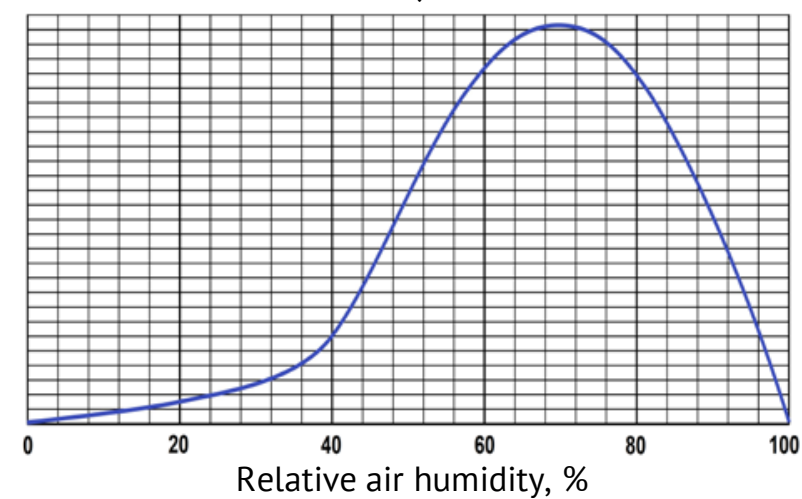

d)

Figure 1. Influence of outside temperature and humidity on the effective diffusion coefficient $D$ for the conditions of Chisinau municipality:

a) average outside air temperature; b) relative air humidity; c) the effective diffusion coefficient $D ;$ d) carbonation rate as a function of relative air humidity.

Because the effective diffusion coefficient $D$ is a function of temperature and humidity, its value changed during the year (Figure $1 \mathrm{c}$ ), having a carbonation rate depending on the relative humidity of the air (Figure $1 \mathrm{~d}$ ). For the calculations, the monthly average value of air temperature and humidity was used, as well as the corresponding values of the effective diffusion coefficient $D$ of the concrete.

As it is shown in Figure 1, the value of the effective diffusion coefficient $D$ changes significantly during the calendar year and these changes must be considered when calculating the carbonation depth of the concrete.

As a result of chemical reactions, calcium carbonate is formed from carbon dioxide, present in the atmosphere in excess, sealing the concrete structure, increasing its strength, 
which leads to the neutralization of concrete [7], reducing its alkalinity. As a result of these reactions, concrete loses its protective properties for concrete reinforcement, generating its corrosion [8]. Heavy rain, which has a low concentration of minerals, washes away easily soluble carbon compounds, which is manifested by discoloration of the concrete surface, reducing its tensile strength and porosity, facilitating the carbonation process [9].

The effects of the chemical attack consist in the changes of the surfaces of the concrete elements [10], which are manifested by the disintegration of the cement stone, the increase of the cracks and joints, the detachment of pieces of concrete, exfoliation of the concrete protection layer of reinforcement, etc. In addition to the physical and chemical factors, the corrosion of the cement stone is also caused by biochemical factors, generated by microorganisms such as anaerobic bacteria, muscles, lichens, underwater algae, fungi etc.

Degradation and gradual destruction of concrete structures because of the corrosion effect depending on the mechanisms of its degradation, mentioned in [11] and [12], must be addressed in terms of durability, taking into account the geo- climate change of the Republic of Moldova.

\section{Corrosion of reinforcement and metal elements}

The effects of extreme climate phenomena can also be manifested by corrosion of metal elements (atmospheric corrosion [13] and [14]), largely through surface defects or cracks in building elements [15]. For example, the periods of the year with heavy rains (spring and autumn), in combination with nitrogen dioxide $\left(\mathrm{NO}_{2}\right)$ in the atmosphere, cause a corrosion rate of steel 4 times faster than in summer or winter. Oxygen $\left(\mathrm{O}_{2}\right)$ in the atmosphere acts as a depolarizer, favoring the corrosion process ( $\left.2 \mathrm{Fe}+\mathrm{O}_{2}=2 \mathrm{FeO}\right)$, having access to the metal surface, especially since the moisture film is thin. Carbon dioxide $\left(\mathrm{CO}_{2}\right)$, with a high concentration in the atmosphere $\left(\mathrm{Fe}+\mathrm{CO}_{2}=\mathrm{FeO}+\mathrm{CO}\right)$, dissolves easily in condensed water on the metal surface, causing rust stains.

The presence of other harmful compounds in the atmosphere, in addition to the three mentioned, leads to very wide changes in the corrosion rate [16].

The process of corrosion in metals can develop in certain areas of the surface, this process is called "localized corrosion", and when the surface is evenly covered with rust "uniform corrosion". Also, corrosion can selectively destroy the metal by cracking, at the grain boundary, called "intercrystalline corrosion", but also propagating through crystals "transcrystalline corrosion", destruction caused by the direction of mechanical stresses of the metal element.

The destruction of metal elements of buildings as a result of electrochemical interaction (dissolving in air, containing moisture or water - called electrolyte) or chemical (formation of metal compounds with chemical agents with high aggressiveness) to the interaction with the external environment can cause significant damage. The damage caused to the national economy by metal corrosion is enormous, it can constitute at least $4 \%$ of the country's annual income.

When local elements (micropyles) appear on the surface of the metal, because of galvanic cells, electrochemical corrosion causes changes in the metal (especially at high ambient temperatures), which is generally manifested by the loss of metal mass as due to reactions, which take place on the surface or in its cracks.

The electrochemical dissolution, which takes place on the surface of the reinforcement in the corrosion process [17], is in the form of two conjugate reactions: 
- anodic reaction - which consists in the passage of metal ion atoms from the crystal lattice in solution, accompanied by the release of electrons.

- cathodic reaction - which consists in the assimilation of these released electrons.

$$
\begin{aligned}
& \bar{e} \mathrm{Me}^{+}+n \mathrm{H}_{2} \mathrm{O} \rightarrow \mathrm{Me}^{+} \cdot n \mathrm{H}_{2} \mathrm{O} \text { (anodic reaction) } \\
& \downarrow \\
& \bar{e}+K^{+} \cdot n \mathrm{H}_{2} \mathrm{O} \rightarrow K+n \mathrm{H}_{2} \mathrm{O} \text { (cathodic reaction). }
\end{aligned}
$$

The electrolytic corrosion reaction of iron in the presence of water is:

$$
\begin{gathered}
\mathrm{Fe}=\mathrm{Fe}^{3+}+3 \mathrm{e}-\mathrm{H}_{2} \mathrm{O}=2 \mathrm{H}^{+}+\mathrm{O}^{2-}+\mathrm{H}_{2} \mathrm{O} \text { (electrolyte) } \\
2 \mathrm{Fe}^{3+}+3 \mathrm{O}^{2-}=\mathrm{Fe}_{2} \mathrm{O}_{3} \text { (rust) }
\end{gathered}
$$

Usually, the chemical destruction of concrete reinforcements and metal surfaces occurs as a result of the action of gases $\left(\mathrm{O}_{2} ; \mathrm{SO}_{2} ; \mathrm{H}_{2} \mathrm{~S} ; \mathrm{HCl}(\mathrm{g}) ; \mathrm{CO} ; \mathrm{CO}_{2} ; \mathrm{H}_{2}\right)$, in an environment with high temperatures, but also because of their corrosion reaction in contact with water and vapors:

$$
2 \mathrm{Fe}+1 / 2 \mathrm{O}_{2}+7 \mathrm{H}_{2} \mathrm{O} \rightarrow 2 \mathrm{Fe}(\mathrm{O}) \mathrm{OH}+4 \mathrm{H}_{2} \mathrm{O} \rightarrow \mathrm{Fe}_{2} \mathrm{O}_{3} \text { (rust) }+6 \mathrm{H}_{2} \mathrm{O}+\mathrm{H}_{2}
$$

Biochemical corrosion is caused by the activity of microorganisms (mostly underwater in stagnant water), which use the metal as a nutrient chemical culture medium or eliminate highly corrosive products due to their metabolism. The products of the vital activity of microorganisms can also be aggressive to metal structures.

Decreasing the protective performance of concrete reinforcement, in terms of crack size, can endanger the safety of construction. Cracks with large openings diminish the rigidity of construction elements, increase their permeability, reduce the resistance to freeze-thaw cycles, and favor the appearance and development of the corrosion phenomenon of steel [18]. According to research, the process of destroying concrete, through the phenomenon of carbonation, attacks the crack walls and the damaged area of contact with the reinforcement. As a rule, the surface to which the carbonation spreads on the sides of the crack is proportional to the size of its opening.

By measuring with a potentiometer, was found that the electrochemical activity of the metal surface in undamaged concrete, in the wettest months of April-September, is characterized by a negative potential and considerable anodic polarization (Figure 2).

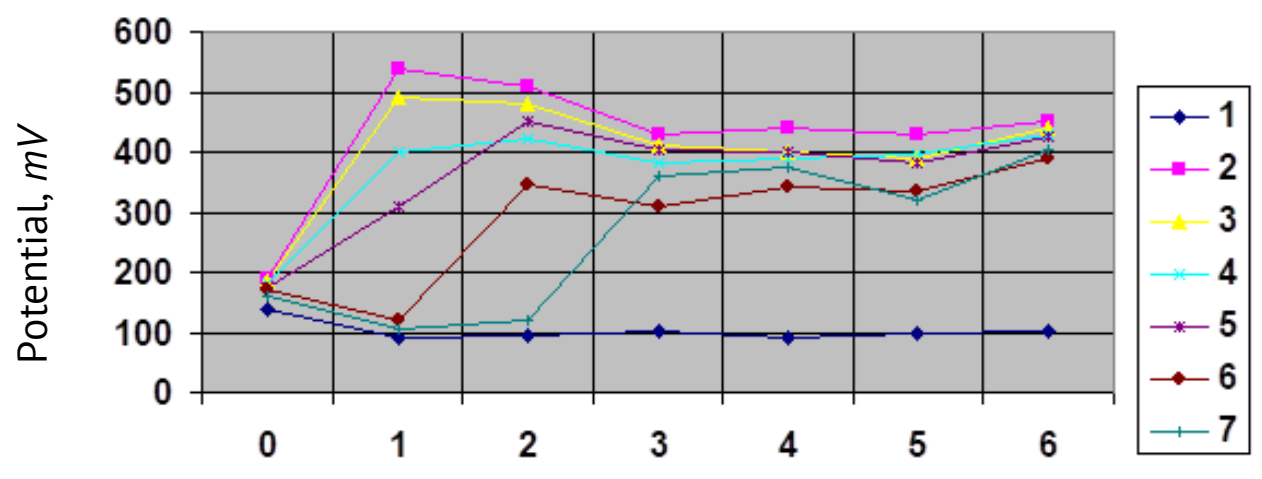

Duration of verifications, months

Figure 2. Change of steel potentials in cracks at periodic wetting with rainwater:

1 - without cracks; $2 \div 7$ - the size of the cracks, accordingly: 0,$7 ; 0,5 ; 0,4 ; 0,2 ; 0,1 ; 0,05$ $\mathrm{mm}$. 
Electrochemical activity on the surface of the reinforcement, in the contact area with the crack, causes a local corrosion. Therefore, the existence of cracks in concrete, the corrosion resistance of the reinforcement, will depend on the specifics of the process and the kinetics of corrosion in different conditions of interaction of construction elements with the corrosive atmospheric environment.

As the variation of alternating wetting cycle's increases, within certain limits, the strength of the corrosion process also increases. Figure 3 shows that in the cracks with a size of $0.5 \mathrm{~mm}$ after the first month of verification, the average corrosion attack was $0.18 \mu \mathrm{m}$, and the increase in the number of cycles $-0.36 \mu \mathrm{m}$.

In constructions moistened with rainwater, the dangerous propagation of corrosion begins only in cracks with openings larger than $0.5 \mathrm{~mm}$, and in cracks with openings smaller than $0.5 \mathrm{~mm}$ the speed of cathodic depolarization decreases, due to the phenomenon of selfcleavage of cracks concrete, which slows down the corrosion process.

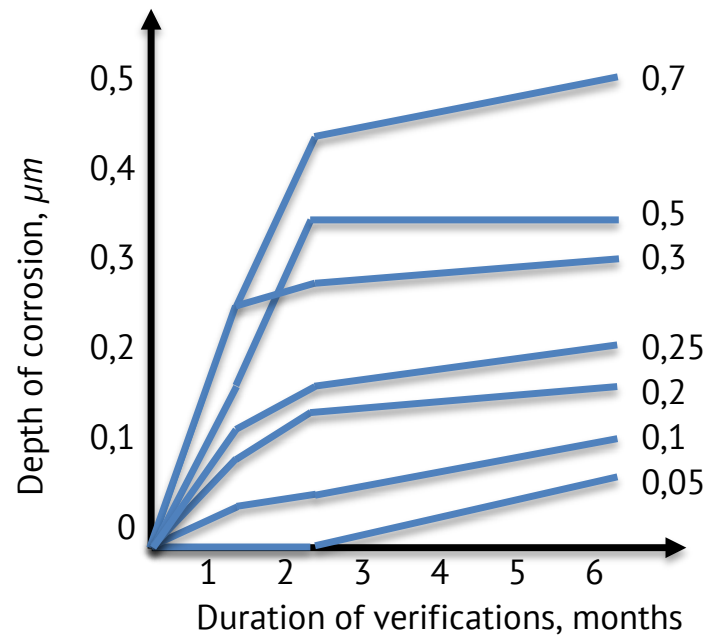

a)

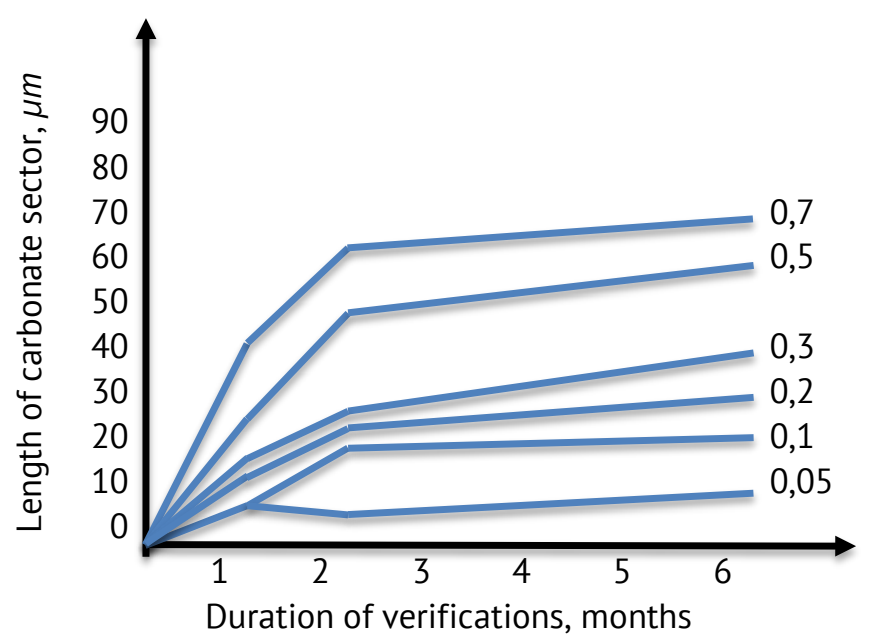

b)

Figure 3. Kinetics of reinforcement corrosion in concrete cracks, in depth (a) and along the surface of steel bars (b), at alternating wetting with rainwater. Next to the curves are indicated the opening sizes of the cracks, in $\mathrm{mm}$.

The experimental results showed that the advanced corrosion of the concrete reinforcements was observed because of the penetration into the concrete of alkaline salts $\left(5 \% \mathrm{NaOH}, 5 \% \mathrm{NH}_{4} \mathrm{OH}\right)$, which reach the surface of the reinforcements in the form of aerosols, contained in the absorbed atmospheric environment.

\section{Degradation of masonry materials}

The degradation of masonry takes place, largely, due to mechanical and physicochemical causes due to the action of climate factors, such as uneven subsidence of the land (sensitive to moisture); rain and snow; the combination of wind and rain; temperature variation; variation of relative humidity; air pollutants; soluble salts [19].

Moisture favors the degradation process of masonry, being a catalyst, which intensifies the degradation through soluble salts and other soluble substances in polluted air.

The capillary action in the porous materials of the masonry creates the suction effect, which produces the rising of water from the soil (which may contain salts in solution) and its retention, which leads to the risk of rapid degradation. In a building, wetlands can have variations in the percentage of humidity - about $10 \%$ of the total floor area, and the costs of 
maintaining these areas can be between $35 \%$ and $50 \%$ of the total costs involved in maintaining the entire building [20].

Soluble salts with different concentrations, circulating through the capillaries of the masonry, generate an osmotic pressure, influencing the spreading surface and the direction of water movement. Water vapor from the air, containing corrosive agents, penetrates the surface of the masonry, until it reaches a saturation equal to the humidity in the surrounding air.

Soluble salts, acting directly on the surface of the masonry or being absorbed by capillary suction, crystallizing destroy the masonry by disintegration. Mortar cements usually contain many minerals, which are soluble in solutions, such as water and weak acids.

The air from industrial areas, being polluted with high concentration acid gases, also contains solid particles, which gradually erode the surface of the masonry. Mortar and masonry blocks being porous materials, they absorb moisture from the air, which damages the mortar over time, the phenomenon being attributed to the complex interaction of constituent materials, environmental factors, and construction techniques. Usually, the mortar is destroyed due to phenomena such as erosion, disintegration, chipping, pickling.

Strong wind gusts accelerate all forms of degradation of masonry and mortar, caused by air pollution.

Thus, due to heavy rains, in combination with air pollutants, efflorescence's appearance on brick or concrete masonry surfaces, due to porous migrations of $\mathrm{Ca}^{2+}$ ions in the form of $\mathrm{Ca}(\mathrm{OH})_{2}$ to the masonry surface, where in contact with $\mathrm{CO}_{2}$ in the atmosphere it forms calcium carbonate $\mathrm{CaCO}_{3}$. Water infiltrations, both in brick, but especially in cement and sand-based mortars, entrain salts, but also other components, and after drying they are deposited on exterior or interior surfaces in the form of white spots (Figure 4).
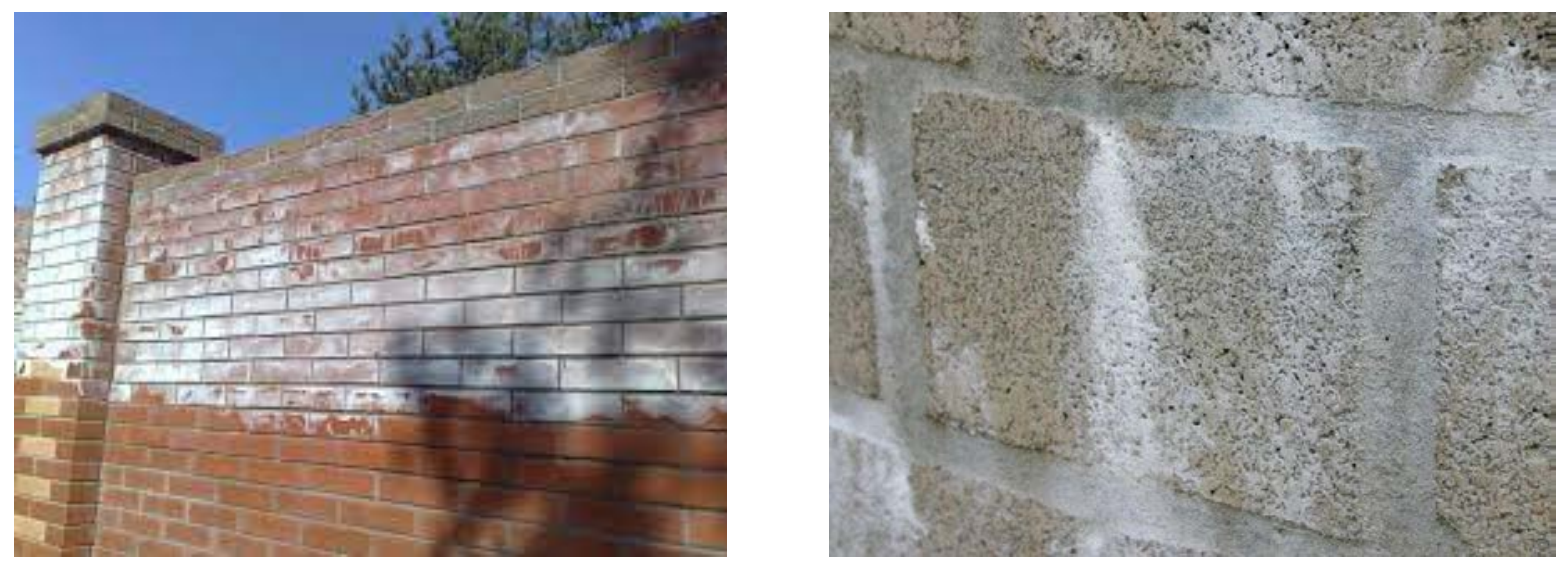

Figure 4. Examples of efflorescence's on brick and concrete masonry surfaces.

\section{Measures to be taken}

Climate change factors also include human activities, changing the environment and through this affecting people, nature and the national economy. The main problems today are the increasing concentration of carbon dioxide $\left(\mathrm{CO}_{2}\right)$ in the atmosphere due to the burning of fossil fuels, corrosive aerosols in the atmosphere, as well as the cement industry, which accounts for about $5 \%$ of $\mathrm{CO}_{2}$ emissions from industrial processes.

Climate change has a devastating impact on the branches and objects of the national economy, such as transport networks, construction and reconstruction of buildings and structures, urban and rural planning, increasingly affecting the health of the population. 
Experts in the field believe that it is necessary to raise awareness of the problem of climate change and its consequences, improve the legal framework and technical regulations, involve the state in this process, develop a system to ensure meteorological and climate risks, create maps of vulnerability individual objects and territories of the country to climate change, development, and implementation of modern mechanisms for managing climate risks.

Important measures must be taken in this regard, such as:

- developing and promoting mechanisms for rapid prevention and intervention in urban and rural areas that demonstrate effectiveness in the event of disasters;

- elaboration of local plans for the reconstruction of the sewerage systems of each locality so that they can take over the excess rainwater in the built-up area, thus preventing floods;

- development of suitable paving systems, through which to infiltrate rainwater at the level of pedestrian traffic alleys, access roads, terraces, as well as for parking lots, storage areas etc.;

- increasing the areas of green plantations and providing water sources for their watering, in order to reduce the risk caused by excessive heat waves;

- revision of the National Annexes to Eurocode 1 [21] in order to update the climate values and the set of climate maps, in order to be used in the process of drafting normative documents related to the actions of climate factors on constructions and their elements, as well as on energy efficiency of buildings;

- integrated approach to project planning, design and management, within the project cycle management, in particular the characteristics related to the quality, technical and performance level of construction products [22], resistant to the actions of the environment, throughout the construction cycle life of buildings, taking into account the environment in which they will be operated;

- the development of construction regulations for green buildings, which ensure the design of construction objects related to the environment as a whole, where local climate conditions play an important role;

- elaboration of normative documents in constructions, which should offer constructive solutions for the improvement of the thermal insulation performances of the buildings, in order to make the energy consumption more efficient, according to the provisions [23];

- implementation of modern architectural concepts in order to achieve constructions, which offer a high degree of use of renewable energy sources, according to the provisions [23];

- production and promotion of materials, constructive solutions, which will cope with the potential effects of climate change;

- the use of durable anti-corrosion protections, their application in optimal conditions of the coating systems in extreme conditions, respecting the selection parameters in the coating and application, which are very important for obtaining a suitable result;

- the application of energy efficiency policy measures throughout the energy chain, the promotion of the use of energy efficient machinery and equipment, renewable energy sources, to final consumers, according to the provisions [24]; 
- elaboration and promotion of professional training programs for architects and designers, on the topic of ensuring the sustainability of constructions and buildings to the effects of climate change.

These measures will provide opportunities for new markets for climate changeresistant technologies, machinery, materials and construction products.

\section{Conclusions}

The effects of climate change cause global warming, generating huge losses for the economy of the Republic of Moldova. To the effects of climate phenomena are added the emissions of a number of air pollutants, such as pollution by ozone, carbon dioxide, nitrogen dioxide and suspended dust, which accelerates the process of reducing the durability of buildings.

The studies carried out demonstrate the extremely variable time and space of the basic climate parameters, which will be able to contribute to the careful selection of measures to mitigate the consequences of climate change on various activities, including the construction sector.

There is a need to raise awareness of the issue of climate change and its consequences, improve the legal framework and technical regulations, involve the state in this process, develop a system to ensure meteorological and climate risks, create maps of vulnerability of individual objects and territories climate change, development, and implementation of modern climate risk management mechanisms.

The causes that lead to the occurrence appearance of the construction degradation phenomena are diverse and can be specific to improper exploitation, but also as a result of extraordinary natural phenomena or results from the humanity's interrelationship with the environment.

The undertaking actions, which will take into account the potential impact of climate change on buildings, will provide opportunities for new markets for construction technologies, machinery, materials and products that are resistant to the destructive actions of the environment.

\section{References}

1. Watt D. Building pathology - Second edition, Blackwell Publishing (2007).

2. Nedealcov M., Răileanu V., Cojocari R., Croitoru Gh., Crivova O. Meteorological-climate risk factors associated with climate change on the territory of the Republic of Moldova. Chisinau 2018. ISBN 978-9975-9611-6-5.

3. Gosav I. Assessing the level of safety of constructions in terms of sustainability. Doctoral thesis, Technical University „Gheorghe Asachi”, lasi (1993).

4. Croitoru Gh., Lvovschi E. The influence of corrosion of concrete elements on the stability of constructions. In: Incercom Bulletin. - Chisinau. - 2012. - No. 1, vol. 2. pp. 33-43. ISSN 1857-3762.

5. Croitoru Gh. Research on the influence of aggressive liquid and gas corrosion on the characteristics of reinforced concrete constructions. In: Incercom Bulletin. - Chisinau 2016 - no. 9, pp. 1-25. ISSN 1857-3762.

6. Croitoru Gh., Proaspăt Ed. Study of carbonation processes of concrete in cracks of agro-zootechnical constructions. In: International Technical-Scientific Conference Current issues of urbanism and spatial planning, UTM Chisinau, $9^{\text {th }}$ Edition, November 16-17, 2018. pp. 299-304. ISBN 978-9975-87-384-0.

7. SM CEN/TR 17310:2020 Carbonation and $\mathrm{CO}_{2}$ uptake in concrete.

8. SM EN 12390-10:2019 Testing hardened concrete - Part 10: Determination of the carbonation resistance of concrete at atmospheric levels of carbon dioxide.

9. SM CR 12793:2017 Measurement of the carbonation depth of hardened concrete.

10. SM SR EN 13577:2011 Chemical attack on concrete - Determination of aggressive carbon dioxide content in water.

11.SM EN 206:2013+A2:2021 Concrete. Specification, performance, production and conformity. 
12. SM 324:2017 National document for application of SM SR EN 206:2016 Concrete. Specification, performance, production and conformity.

13.SM EN ISO 9223:2016 Corrosion of metals and alloys. Corrosivity of atmospheres. Classification, determination and estimation.

14. SM EN ISO 12944-2:2018 Paints and varnishes. Corrosion protection of steel structures by protective paint systems. Part 2: Classification of environments.

15. Croitoru Gh. Research on the influence of atmospheric humidity on the corrosion rate of steel in the cracks of reinforced concrete elements. UTM. In: VII International Technical-Scientific Conference Current problems of urbanism and spatial planning, Vol. III. - November 13-15, 2014. Chisinau, pp. 70-73. ISBN 978-9975-71-5836.

16. Croitoru Gh. Modeling atmospheric corrosion of metals. In: Proceedings of the $39^{\text {th }}$ International Seminar on Modelling and Optimization of Composites, Sensible experiment in materials science, Ukraine, Odessa, 26-27 April 2000, MOK'39, pp. 136-137. ISBN 966-549-402-3.

17. Croitoru Gh., Pruteanu N., Uzun N. Research into the structure of concrete and its influence on the corrosion resistance of reinforcement. Incercom Bulletin. Chisinau. 2012. no. 1, vol. 2. pp. 62-73. ISSN 1857-3762.

18. Croitoru Gh. Study of the initiation and development of cracks in reinforced concrete constructions and the specificity of reinforcement corrosion in these areas. In: Incercom Bulletin. Chisinau. May 23 - 2014. No. 5CN, pp. 5-12. ISSN 1857-3762.

19. Croitoru Gh. Study of the state of limestone wall stone materials under the influence of aggressive environments. In: Materials of the III International Scientific and Practical Conference "Methodology and principles of pricing in construction. Innovative technologies in the construction industry and their implementation". Belarus, Minsk, December 01-02, 2015, pp.100-105. ISBN 978-985-90304-7-5.

20. Chew M.Y.L., Nayanthara D.S. Factors affecting watertightness in wet area of high-rise residential buildings. Archit Sci Rev 45(4), pp. 375-383 (2002).

21. SM EN 1991 Eurocode 1: Actions on structures.

22.Georgescu D., Apostu A., Croitoru Gh. Application of methods based on sustainability performance and establishing the fields of use of concrete prepared with component materials from the Republic of Moldova. Romanian Journal of Materials, 2017, vol. 47 No. 2, pp. 210 -216. ISSN 2457-502X.

23. Law no. 128 of 11.07.2014 on the energy performance of buildings. (Published: 10.10 .2014 in the Official Gazette No. 297-309, art. No: 609. Date of entry into force: 01.01.2015).

24. Law no. 139 of 19.07.2018 on energy efficiency. (Published: 17.08 .2018 in the Official Gazette No. 309-320 art. 476). 